\title{
Benzothiazole Derivatives as Multifunctional Antioxidant Agents for Skin Damage: Structure-Activity Relationship of a Scaffold Bearing a Five-Membered Ring System
}

\author{
Ernestine Nicaise Djuidje ${ }^{1,+}$, Riccardo Barbari ${ }^{2,+}{ }^{\mathbb{D}}$, Anna Baldisserotto ${ }^{1, *(\mathbb{D}}$, Elisa Durini ${ }^{1}$ (D), Sabrina Sciabica ${ }^{1}$, \\ Jan Balzarini ${ }^{3}$, Sandra Liekens ${ }^{3}$, Silvia Vertuani ${ }^{1, *}$ and Stefano Manfredini ${ }^{1}$ (D)
}

1 Department of Life Sciences and Biotechnology, Master Course in Cosmetic Science and Technologies, University of Ferrara, Via L. Borsari 46, 44121 Ferrara, Italy; djdrst@unife.it (E.N.D.); elisa.durini@unife.it (E.D.); scbsrn@unife.it (S.S.); mv9@unife.it (S.M.)

2 Department of Chemical and Pharmaceutical Sciences, University of Ferrara, Via Fossato di Mortara 17-19, 44121 Ferrara, Italy; riccardo.barbari@unife.it

3 Laboratory of Virology and Chemotherapy, Rega Institute for Medical Research, Department of Microbiology and Immunology, KU Leuven, University of Leuven, B-3000 Leuven, Belgium;

jan.balzarini@kuleuven.be (J.B.); sandra.liekens@rega.kuleuven.be (S.L.)

* Correspondence: bldnna@unife.it (A.B.); vrs@unife.it (S.V.); Tel.: +39-0532-455258 (A.B.); +39-0532-455294 (S.V.)

$\dagger$ These authors contributed equally to this work.

check for updates

Citation: Djuidje, E.N.; Barbari, R.; Baldisserotto, A.; Durini, E.; Sciabica, S.; Balzarini, J.; Liekens, S.; Vertuani, S.; Manfredini, S. Benzothiazole Derivatives as Multifunctional Antioxidant Agents for Skin Damage: Structure-Activity Relationship of a Scaffold Bearing a Five-Membered Ring System. Antioxidants 2022, 11, 407. https://doi.org/10.3390/ antiox11020407

Academic Editors: André Rolim Baby and Catarina Rosado

Received: 27 January 2022

Accepted: 15 February 2022

Published: 17 February 2022

Publisher's Note: MDPI stays neutral with regard to jurisdictional claims in published maps and institutional affiliations.

Copyright: (c) 2022 by the authors. Licensee MDPI, Basel, Switzerland. This article is an open access article distributed under the terms and conditions of the Creative Commons Attribution (CC BY) license (https:// creativecommons.org/licenses/by/ $4.0 /)$.

\begin{abstract}
Skin diseases often give multifactorial damages; therefore, the development of multifunctional compounds represents a suitable approach especially against disorders that are induced by oxidative stress. Thus, taking into account the successful results we achieved on benzimidazoles, we have devised a new series of isosteric benzothiazoles and investigated their antioxidant, photoprotective, antifungal and antiproliferative activity. Particular attention has been paid to synergistic antioxidant and photoprotective properties. For compounds $\mathbf{9 a}$ and $\mathbf{1 0 a}$, a multifunctional profile was outlined, supported by an excellent filtering capacity, mainly UVB, which has higher capacities than those of the reference PBSA which is currently in the market as a UV sunscreen filter. The two compounds were also the best in terms of growth inhibition of dermatophytes and Candida albicans, and 10a also showed good antioxidant activity. Furthermore, 9a was also effective on melanoma tumor cells (SK-Mel 5), making these compounds good candidates in the development of new skin protective and preventive agents.
\end{abstract}

Keywords: benzothiazole; multifunctional; UV filter; antioxidant; antimicrobial; cosmeceutical

\section{Introduction}

Many diseases, defined as multifactorial because they are caused by multiple genetic and environmental factors, are highly variable and heterogeneous, involving multiple organ systems, tissues and potential targets.

These multifactorial diseases, which involve two or more indications and have very complex etiopathologies, include atherosclerosis, Alzheimer's disease (AD), rheumatoid arthritis, cancer, metabolic syndrome, asthma, osteoarthritis, diabetic complications, malaria, tuberculosis, neurotrauma, various CNS disorders and multiple sclerosis-diseases that are currently treated or moderated by numerous drugs belonging to different therapeutic classes [1].

It is known that the traditional approach of treating multifactorial diseases with a single drug has proved ineffective precisely because the single drug is unable to act on different sites [2].

For this reason, in order to ensure the effective and safe treatment of these diseases, various strategies have evolved, including complex drug therapies or drug cocktails and 
drug combinations [3]. However, even these approaches have shown several disadvantages which include, among the main ones, poor patient compliance, possible drug interactions, complex pharmacokinetic and pharmacodynamic relationships related to the variable metabolism from patient to patient [4-7]. This is why the focus has been oriented on the design of single molecules with a broad-spectrum activity profile: these new drugs, called multifunctional drugs, have a better therapeutic index due to the synergistic effects or fewer side effects [8-11]. It is known that inflammation and oxidative stress are closely related to the pathogenesis of various life-threatening diseases such as cancer, atherosclerosis and diabetes [12-15]. Designing and developing new drugs capable of preventing diseases caused by oxidative stress and inflammation has assumed great importance in recent years. In this context, the chemistry of heterocycles has found a significant role, as has that of benzothiazoles-fused bicyclic systems with a biological profile of interest with known antiinflammatory, antioxidant and antitumor effects [16]. Benzothiazoles constitute the central nucleus of several drugs with different biological properties, such as viozan, probenazole, ethoxazolamide and riluzole.

Benzothiazole derivatives have also attracted constant interest in various branches of chemical research, including dyes [17], drugs and polymer chemistry [18]. Many benzothiazoles have been patented for a variety of biological activities including antituberculous, antiproliferative, antibacterial, anthelmintic, antioxidant and antimicrobial $[19,20]$. There are also drugs containing benzothiazole scaffolds such as: 2-amino-6trifluoromethoxybenzothiazole, used in the treatment of amyotrophic lateral sclerosis; 2thiocyanomethylthio-benzothiazole (TCMTB-60), a fungicide also used for the prevention of fungal attacks of the skin; 1- (6-methoxy-2-benzothiazolyl) -3-phenyl urea (frentizole), an antimicrobial agent; Ethoxzolamide, which is used in the treatment of glaucoma and duodenal ulcers and is a diuretic agent; and 2- (4-amino-3-methylphenyl) benzothiazole, an anticancer agent [21]. Furthermore, many benzothiazole derivatives are currently in different stages of clinical trials [22].

Our current interests are related to the design and synthesis of multifunctional compounds capable of both counteracting oxidative damage caused by free radicals and filtering $\mathrm{UV}$, thus protecting skin, during sun exposure, from excessive oxidative stress. UV radiation is in fact the main cause of the formation of reactive oxygen (ROS) and nitrogen (RNS) species related to degenerative processes such as skin photoaging, inflammation and skin diseases (erythema and hyperpigmentation), as well as the carcinogenesis process [23,24]. Furthermore, following our current systematic approach, we also investigate antimicrobial activities.

In particular, our previous studies concerned the design and synthesis of libraries of benzofuranhydrazones, indole-hydrazones, aryl-benzimidazoles, benzimidalzolidrazones and benzothiazole derivatives [25-29] designed to identify molecules endowed with at least a dualistic activity. These compounds resulted in a high antioxidant capacity and a good profile in photoprotection or anticancer activity. This type of dualism would protect, at the same time, against the damage generated by UVA (oxidative damage promoted by free radicals) and from UVB, both known to be related to the direct damage of DNA and the onset of skin tumors [30].

During our previous study on the structure-activity relationship of a class of benzimidazole derivatives, starting from the well-known commercial PBSA filter (2-Phenyl-1Hbenzo[d]imidazole-5-sulfonic acid) (Figure 1), we discovered a very interesting compound featured by a pyrrole on the benzimidazole ring in position 2 and no substituent in position 6. This compound (10, Figure 1) emerged among others of the series that had different heterocycles (furan and thiophene) in position 2 and showed an excellent multifunctional profile. In particular, compound $\mathbf{1 0}$ exhibited $\mathrm{IC}_{50}$ values towards the tested dermatophytes lower than $2 \mu \mathrm{g} / \mathrm{mL}$, a good antioxidant profile in vitro (DPPH and FRAP tests), and finally showed an $\mathrm{IC}_{50}$ equal to $9.7 \mu \mathrm{M}$ towards human melanoma cells. To date, the mechanisms underlying this multifunctional structure-activity relationship are not known, but the interesting antioxidant and anti-melanoma multifunctional profile of compound $\mathbf{1 0}$ [31] led 
us to choose it as a lead compound to continue investigating key positions and structural features for new development.<smiles>O=S(=O)(O)c1ccc2[nH]c(-c3ccccc3)nc2c1</smiles>

PBSA<smiles>c1c[nH]c(-c2nc3ccccc3[nH]2)c1</smiles>

Compound 10

Figure 1. PBSA and Lead compound 10.

In the present study, we decided to implement an isosteric modification to the scaffold of the lead compound, thus going from a benzimidazole nucleus to a benzothiazole, and to maintain the previously investigated five-membered rings in position 2 (pyrrole, thiophene, furan) [31], isosters of the benzene ring present in PBSA, which are of particular interest in the field of pharmaceutical chemistry for their antineoplastic, anti-inflammatory and antimicrobial profile [32]. In position 6 of the benzothiazole ring, similarly to the previous series, hydrogen, carboxylic acid and sulfonamide were inserted.

Nine derivatives were then synthesized, which include both already-known and newly synthesized compounds. To investigate the possible multifunctional profile, all derivatives were tested to evaluate their antioxidant, photoprotective, antifungal and antiproliferative activity.

\section{Materials and Methods}

\subsection{General}

All reagents were purchased from commercial sources and used without further purification.

Silica gel plates were used to perform TLC analyses (Macherey-Nagel Poligram SIL G/UV254 0.20 mm, GmbH \& Co. KG Neumann-Neander-Str. 6-8, 52,355 Dueren, Germany) and visualized at $254 \mathrm{~nm}$ and/or with a solution of $\mathrm{KMnO}_{4}(1 \%)$.

Molecular weights were determined by ESI (Micromass ZMD 2000), and the values are expressed as $[\mathrm{MH}]+$. A Spectrum 100 FT-IR Spectrometer (PerkinElmer) was used to obtain IR spectra. Melting points were measured with a Stuart melting point apparatus. ${ }^{1} \mathrm{H}-\mathrm{NMR}$ and ${ }^{13} \mathrm{C}-\mathrm{NMR}$ were registered on VXR-200 Varian spectrometer at $200 \mathrm{MHz}$ and $400 \mathrm{MHz}$, using tetramethylsilane (TMS) as an internal standard. Chemical shifts are expressed in $\delta$ units (ppm) relative to the residual deuterated solvent signals of $\mathrm{D}_{2} \mathrm{O}$ and $\left(\mathrm{CD}_{3}\right)_{2} \mathrm{SO}$. The following contractions indicate signal multiplicity and assignment- $\mathrm{s}$ (singlet), $\mathrm{d}$ (doublet), t (triplet), q (quartet), m (multiplet), brs (broad singlet) and dd (doublet of doublets), Bzt (benzothiazole). UV-VIS spectrophotometer (Shimadzu UV-2600) or on a Life Science UV /VIS spectrophotometer (Beckman Coulter., DU ${ }^{\circledR} 530$, Single Cell Module, Beckman Coulter s.r.l., Via Roma, 108-Palazzo F1, Centro Cassina Plaza 20,060-Cassina De' Pecchi, Milano, Italia) were used for UV spectrophotometric analyses. Photostability of the compounds was evaluated with Atlas Suntest CPS+ solar simulator, (URAI S.p.a., Assago, Milano, Italy). WW5 PMMA plates were from Schonberg GmbH (Munich, Germany). Sabouraud dextrose agar (SDA) was bought by Sigma-Aldrich SRL, Milano, Italy.

\subsection{Chemistry}

\subsubsection{Synthesis of 2-Substitutedbenzothiazoles}

2-aminothiophenol $(3.2 \mathrm{mmol})$ and aldehyde $(3.2 \mathrm{mmol})$ were stirred in ethanol $(3.5 \mathrm{~mL})$ at room temperature; then a solution of sodium hydrosulfite (2 eq.) in $3 \mathrm{~mL}$ of water was added, and the reaction mixture was refluxed for $12 \mathrm{~h}$. After completion, the reaction was allowed to cool to room temperature and concentrated under vacuum. $\mathrm{HCl}$ $2 \mathrm{~N}$ was added and the resulting suspension was filtered to obtain the crude solid which was dried and recrystallized to obtain compounds 8a-10a. 
Synthesis of 2-(1H-Pyrrol-2-Yl)benzothiazole (8a)

Brown solid in yield $69 \%$; m.p. $=132{ }^{\circ} \mathrm{C}$. IR $(\mathrm{KBr}) \mathrm{cm}^{-1}$ : 3122.71, 1557.75, 1486.59, 1278.61, 1039.77, 739.33. ${ }^{1} \mathrm{H}$ NMR (400MHz, DMSO-d6): $\delta$ (ppm) 12.10 (brs, $\left.1 \mathrm{H}, \mathrm{NH}\right), 8.02$ $\left(\mathrm{dd}, \mathrm{J}_{1}=8, \mathrm{~J}_{2}=0.8,1 \mathrm{H}, \mathrm{Ar}\right), 7.87(\mathrm{~d}, \mathrm{~J}=8,1 \mathrm{H}, \mathrm{Ar}), 7.45(\mathrm{t}, 1 \mathrm{H}, \mathrm{Ar}), 7.34(\mathrm{t}, 1 \mathrm{H}, \mathrm{Ar}), 7.02$ (m, 1H, Pyr), 6.83 (m, 1H, Pyr), 6.22 (m, 1H, Pyr). ${ }^{13} \mathrm{C}$ NMR (400MHz, DMSO-d6): $\delta(\mathrm{ppm})$ 160.27 (Ar), 153.93 (Bzt), 133.88 (Ar), 126.80 (Ar), 126.01 (Pyr), 124.91 (Ar), 123.70 (Pyr), $122.50(\mathrm{Ar}), 121.96(\mathrm{Ar}), 112.87(\mathrm{Pyr}), 110.56(\mathrm{Pyr})$. ESI-MS $[\mathrm{M}+\mathrm{H}]^{+}$: calcd for $\mathrm{C}_{11} \mathrm{H}_{8} \mathrm{~N}_{2} \mathrm{~S}$, 200.04; found 200.33.

Synthesis of 2-(Furan-2-Yl)benzothiazole (9a)

Yellow solid in yield $48 \%$; m.p. $=103{ }^{\circ} \mathrm{C}$. IR $(\mathrm{KBr}) \mathrm{cm}^{-1}$ : 1579.62, 1503.96, 1245.20, 1011.25, 896.56, 74614. ${ }^{1} \mathrm{H}$ NMR (400MHz, DMSO-d6): $\delta$ (ppm) $8.13\left(\mathrm{dd}, \mathrm{J}_{1}=10, \mathrm{~J}_{2}=1.6\right.$, $1 \mathrm{H}, \mathrm{Ar}), 8.00(\mathrm{~m}, 2 \mathrm{H}, \mathrm{Ar}, \mathrm{Fur}), 7.52(\mathrm{t}, 1 \mathrm{H}, \mathrm{Ar}), 7.45(\mathrm{t}, 1 \mathrm{H}, \mathrm{Ar}), 7.35\left(\mathrm{dd}, \mathrm{J}_{1}=3.6, \mathrm{~J}_{2}=0.86\right.$, 1H, Fur), 6.78 (m, 1H, Fur). ${ }^{13} \mathrm{C}$ NMR (400MHz, DMSO-d6): $\delta$ (ppm) 157.38 (Ar), 153.88 (Bzt), 148.48 (Fur), 146.72 (Fur), 134.22 (Ar), 127.34 (Ar), 125.99 (Ar), 123.21 (Ar), 122.99 (Ar), 113.63 (Fur), 112.48 (Fur). ESI-MS [M+H] $]^{+}$: calcd for $\mathrm{C}_{11} \mathrm{H}_{7} \mathrm{NOS}$, 201.02; found 201.28.

Synthesis of 2-(Thiophen-2-Yl)benzothiazole (10a)

Brown solid in yield $87 \%$; m.p. $=99^{\circ} \mathrm{C}$. IR $(\mathrm{KBr}) \mathrm{cm}^{-1}: 1540.86,1415.85,1222.86$, 758.38, 710.37. ${ }^{1} \mathrm{H}$ NMR (400MHz, DMSO-d6): $\delta(\mathrm{ppm}) 8.08\left(\mathrm{dd}, \mathrm{J}_{1}=8, \mathrm{~J}_{2}=2,1 \mathrm{H}, \mathrm{Ar}\right), 7.98$ $\left(\mathrm{dd}, \mathrm{J}_{1}=8.2, \mathrm{~J}_{2}=2,1 \mathrm{H}, \mathrm{Ar}\right), 7.84(\mathrm{~m}, 2 \mathrm{H}, \mathrm{Thio}), 7.51(\mathrm{t}, 1 \mathrm{H}, \mathrm{Ar}), 7.42(\mathrm{t}, 1 \mathrm{H}, \mathrm{Ar}), 7.23(\mathrm{~m}$, 1H, Thio). ${ }^{13} \mathrm{C}$ NMR (400MHz, DMSO-d6): $\delta$ (ppm) 161.33 (Ar), 153.50 (Ar), 136.78 (Ar), 134.66 (Thio), 131.29 (Thio), 130.12 (Thio), 129.21 (Thio), 127.20 (Ar), 125.97 (Ar), 122.89 (Ar), 122.75 (Ar). ESI-MS [M+H] $]^{+}$: calcd for $\mathrm{C}_{11} \mathrm{H}_{7} \mathrm{NS}_{2}$, 217.00; found 218.27.

Compounds 2 and 3 were synthetized as previously reported and their analytical and spectra data are in agreement with the literature [33].

Compounds $\mathbf{5}$ and $\mathbf{6}$ were synthesized and characterized as previously reported and their analytical and spectra data are in agreement with the literature [28].

\subsubsection{Synthesis of 2,6-Disubstitutedbenzothiazoles}

4-amino-3-mercaptobenzoic acid ( $0.49 \mathrm{~g}, 2.9 \mathrm{mmol}$ ) or bis(2-amino-4-benzenesulfonamide) disulfide $(2.35 \mathrm{~g}, 5.8 \mathrm{mmol})$ and the corresponding benzaldehydes were stirred in ethanol $(10 \mathrm{~mL})$ at room temperature; then a solution of sodium hydrosulfite ( 1 eq. in $5 \mathrm{~mL} \mathrm{H}_{2} \mathrm{O}$ ) was added, and the mixture was refluxed for $36 \mathrm{~h}$. After cooling, the solution was concentrated in vacuum and the residue was treated with $\mathrm{HCl} 2 \mathrm{~N}(15 \mathrm{~mL})$, filtered and recrystallized in $\mathrm{MeOH} / \mathrm{H}_{2} \mathrm{O}$.

\section{2-(1H-Pyrrol-2-Yl)benzothiazole-6-Carboxylic Acid (8b)}

Brown solid in yield $34 \%$; m.p. $>250{ }^{\circ} \mathrm{C}$. IR $(\mathrm{KBr}) \mathrm{cm}^{-1}: 3188.62,1575.50,1484.98$, 1269.66, 826.64. ${ }^{1} \mathrm{H}$ NMR (400MHz, DMSO-d6): $\delta$ (ppm) 12.92 (brs, $\left.1 \mathrm{H}, \mathrm{COOH}\right), 12.20$ (s, 1H, NH), 8.63 (s, 1H, Ar), 7.93 (m, 2H, Ar), 7.07 (s, 1H, Pyr), 6.92 (s, 1H, Pyr), 6.25 (s, 1H, Pyr). ${ }^{13}$ C NMR (400MHz, DMSO-d6): $\delta$ (ppm) 166.84 (COOH), 163.01 (Ar), 156.40 (Bzt), 133.52 (Ar), 127.39 (Ar), 126.41 (Pyr), 125.30 (Ar), 124.03 (Ar), 123.92 (Ar), 120.99 (Pyr), 113.39 (Pyr), 110.43 (Pyr). ESI-MS [M+H] ${ }^{+}$: calcd for $\mathrm{C}_{12} \mathrm{H}_{8} \mathrm{~N}_{2} \mathrm{O}_{2} \mathrm{~S}$, 244.03; found 244.38.

\section{2-(Furan-2-Yl)benzothiazole-6-Carboxylic Acid (9b)}

Brown solid in yield $30 \%$; m.p. $>250{ }^{\circ} \mathrm{C}$. IR (KBr) cm ${ }^{-1}$ : 3100-2579, 1712.80, 1582.90, 1498.68, 1217.68, 752.23, 723.83. ${ }^{1} \mathrm{H}$ NMR (400MHz, DMSO-d6): $\delta$ (ppm) 13.10 (brs, $1 \mathrm{H}$, $\mathrm{COOH}), 8.75(\mathrm{~d}, \mathrm{~J}=1.6,1 \mathrm{H}, \mathrm{Ar}), 8.05(\mathrm{~m}, 3 \mathrm{H}, 2 \mathrm{H} \mathrm{Ar}, 1 \mathrm{H} \mathrm{Fur}), 7.43\left(\mathrm{dd}, \mathrm{J}_{1}=3.6, \mathrm{~J}_{2}=0.4,1 \mathrm{H}\right.$, Fur), 6.81 (m, 1H, Fur). ${ }^{13} \mathrm{C}$ NMR (400MHz, DMSO-d6): $167.25(\mathrm{COOH}), 160.62$ (Ar), 156.61 (Ar),148.20 (Fur), 147.30 (Fur), 134.34 (Ar), 128.14 (Ar), 127.96 (Ar), 124.95 (Ar), 122.80 (Ar), 113.77 (Fur), 113.45 (Fur). ESI-M [M+H] ${ }^{+}$: calcd for $\mathrm{C}_{12} \mathrm{H}_{7} \mathrm{NO}_{3} \mathrm{~S}$, 245.01; found 245.23. 
2-(Thiophen-2-Yl)benzothiazole-6-Carboxylic Acid (10b)

White solid in yield $48 \%$; m.p. $>250{ }^{\circ} \mathrm{C}$. IR $(\mathrm{KBr}) \mathrm{cm}^{-1}=3310,1679.28,1539.53$, 1418.05, 1280.39, 1056.95, 771.55, 700.35. ${ }^{1} \mathrm{H}$ NMR (400MHz, DMSO-d6): $\delta(\mathrm{ppm}) 8.72(\mathrm{~d}$, $\mathrm{J}=0.8,1 \mathrm{H}, \mathrm{Ar}), 8.03(\mathrm{~m}, 2 \mathrm{H}, 1 \mathrm{H} \mathrm{Ar}, 1 \mathrm{H}$ Thio), $7.91(\mathrm{~m}, 2 \mathrm{H}, 1 \mathrm{H} \mathrm{Ar}, 1 \mathrm{H}$ Thio $), 7.26(\mathrm{t}, 1 \mathrm{H}$, Thio). ${ }^{13} \mathrm{C}$ NMR (400MHz, DMSO-d6): $\delta$ (ppm) 167.28 (COOH), 164.80 (Ar), 156.35 (Bzt), 136.46 (Ar), 134.89 (Thio), 132.20 (Thio), 131.00 (Thio), 129.43 (Thio), 128.11 (Ar, Ar), 124.80 (Ar), 122.58 (Ar). ESI-MS [M+H] $]^{+}$: calcd for $\mathrm{C}_{12} \mathrm{H}_{7} \mathrm{NO}_{2} \mathrm{~S}_{2}, 260.99$; found 261.16.

\section{2-(1H-Pyrrol-2-Yl)benzothiazole-6-Sulfonamide (8c)}

Reddish brown solid in yield 31\%; m.p. $>250{ }^{\circ} \mathrm{C}$. IR $(\mathrm{KBr}) \mathrm{cm}^{-1}$ : 3266.84, 1479.82, 1293.60, 752.49. ${ }^{1} \mathrm{H}$ NMR (400MHz, DMSO-d6): $\delta$ (ppm) 12.14 (s, $1 \mathrm{H}, \mathrm{NH}$ Pyr), 8.47 (d, $\mathrm{J}=1.6,1 \mathrm{H}, \mathrm{Ar}), 7.98(\mathrm{~d}, \mathrm{~J}=8.4,1 \mathrm{H}, \mathrm{Ar}), 7.86\left(\mathrm{dd}, \mathrm{J}_{1}=8.4 \mathrm{~J}_{2}=2,1 \mathrm{H}, \mathrm{Ar}\right), 7.41(\mathrm{~s}, 2 \mathrm{H}$, $\left.\mathrm{NH}_{2}\right), 7.08(\mathrm{~m}, 1 \mathrm{H}, \mathrm{Pyr}), 6.93(\mathrm{~m}, 1 \mathrm{H}, \mathrm{Pyr}), 6.26(\mathrm{~m}, 1 \mathrm{H}, \mathrm{Pyr}) .{ }^{13} \mathrm{C}$ NMR $(400 \mathrm{MHz}, \mathrm{DMSO}-$ d6): 163.61 (Ar), 155.81 (Bzt), 140.08 (Ar), 134.01 (Ar), 125.64 (Pyr), 124.71 (Ar), 124.55 (Ar), 122.02 (Pyr), 120.69 (Ar), 114.10 (Pyr), 111.11 (Pyr). ESI-MS [M+H] ${ }^{+}$: calcd for $\mathrm{C}_{11} \mathrm{H}_{9} \mathrm{~N}_{3} \mathrm{O}_{2} \mathrm{~S}_{2}$, 279.01; found 279.32

\section{2-(Furan-2-Yl)benzothiazole-6-Sulfonamide (9c)}

Pale brown solid in yield $29 \%$; m.p. $>250{ }^{\circ} \mathrm{C}$. IR $(\mathrm{KBr}) \mathrm{cm}^{-1}$ : 3265.06, 1504.84, 1304.50, 755.31, 722.11. ${ }^{1} \mathrm{H}$ NMR $(400 \mathrm{MHz}$, DMSO-d6): $\delta(\mathrm{ppm}) 8.64(\mathrm{~s}, 1 \mathrm{H}, \mathrm{Ar}), 8.14(\mathrm{~d}, \mathrm{~J}=8.4,1 \mathrm{H}$, Ar), $8.05(\mathrm{~m}, 1 \mathrm{H}, \mathrm{Fur}), 7.95(\mathrm{~d}, \mathrm{~J}=8.4,1 \mathrm{H}, \mathrm{Ar}), 7.49\left(\mathrm{~s}, 2 \mathrm{H}, \mathrm{NH}_{2}\right), 7.44(\mathrm{~m}, 1 \mathrm{H}, \mathrm{Fur}), 6.81(\mathrm{~m}$, 1H, Fur) ${ }^{13} \mathrm{C}$ NMR (400MHz, DMSO-d6): 160.69 (Ar), 155.52 (Bzt), 148.07 (Fur), 147.38 (Fur), 141.19 (Ar), 134.24 (Ar), 124.87 (Ar), 123.33 (Ar), 121.25 (Ar), 113.80 (Fur), 113.55 (Fur). ESI-M [M+H] $]^{+}$: calcd for $\mathrm{C}_{11} \mathrm{H}_{8} \mathrm{~N}_{2} \mathrm{O}_{3} \mathrm{~S}_{2}, 280.00$; found 280.43 .

2-(Thiophen-2-Yl)benzothiazole-6-Sulfonamide (10c)

Pale yellow solid in yield 54\%; m.p. $>250^{\circ} \mathrm{C}$. IR $(\mathrm{KBr}) \mathrm{cm}^{-1}$ : 3257.40, 1537.10, 1474.81, 1155.00, 834.44, 717.29. ${ }^{1} \mathrm{H}$ NMR (400MHz, DMSO-d6): $\delta(\mathrm{ppm}) 8.60$ (d, J = 1.8, 1H, Ar), $8.13(\mathrm{~d}, \mathrm{~J}=9,1 \mathrm{H}, \mathrm{Ar}), 7.92\left(\mathrm{~m}, 3 \mathrm{H}, 1 \mathrm{H} \mathrm{Ar}, 2 \mathrm{H}\right.$ Thio), $7.46\left(\mathrm{~s}, 2 \mathrm{H},-\mathrm{NH}_{2}\right), 7.27(\mathrm{t}, 1 \mathrm{H}$, Thio). ${ }^{13} \mathrm{C}$ NMR (400MHz, DMSO-d6): $\delta(\mathrm{ppm}) 164.90$ (Ar), 155.26 (Bzt), 141.24 (Ar), $136.30(\mathrm{Ar})$, 134.82 (Thio), 132.32 (Thio), 131.15 (Thio), 129.46 (Thio), 124.80 (Ar), 123.12 (Ar), 121.11 (Ar). ESI-MS $[\mathrm{M}+\mathrm{H}]^{+}$: calcd for $\mathrm{C}_{11} \mathrm{H}_{8} \mathrm{~N}_{2} \mathrm{O}_{2} \mathrm{~S}_{3}$, 295.97; found 296.18 .

\subsection{Biological Activity}

2.3.1. Antioxidant Profile

In Vitro DPPH Test

The assay performed is adapted from Wang et al. [34]. Briefly, $0.750 \mathrm{~mL}$ of $1 \mathrm{mg} / \mathrm{mL}$ solutions of the tested compounds was treated with $1.5 \mathrm{~mL}$ of DPPH solution in $\mathrm{MeOH}$. The absorbance of samples, stored for $30 \mathrm{~min}$ at room temperature in the dark, was read on the spectrophotometer at $517 \mathrm{~nm}$. The values obtained were converted into a radical inhibition percentage (\%) by Equation (1).

$$
\text { DPPH radical scavenging capacity }(\%)=[1-\mathrm{A} 1 / \mathrm{A} 0] \times 100 \%
$$

where A0 and A1 were, respectively, the absorbance without and with the sample. Subsequently, the compound with the best profile was tested in order to determine the $\mathrm{IC}_{50}$ $(\mu \mathrm{g} / \mathrm{mL})$. A linear regression plot is performed to calculate the actual sample concentration required to eliminate $50 \%$ of the DPPH free radicals.

\section{Ferric Reducing Antioxidant Power Assay (FRAP)}

The FRAP assay is a widely used method based on a colorimetric reaction linked to a redox and on the use of antioxidants as reducing agents.

The test evaluates the capacity of a sample to reduce ferric to ferrous ions in the presence of TPTZ (2,4,6-tripyridyl-s-triazine). The reaction mixture consists of $0.1 \mathrm{M}$ acetate 
buffer $\mathrm{pH}$ 3.6, $10 \mathrm{mmol} / \mathrm{L} \mathrm{TPTZ} \mathrm{in} 40 \mathrm{mmol} / \mathrm{HCl}$, and $20 \mathrm{mmol} / \mathrm{L}$ ferric chloride in the ratio 10/1/1 (v:v:v) as described by Benzie et al. [35]. A total of $1.9 \mathrm{~mL}$ of reagent was added to $0.1 \mathrm{~mL}$ of suitably diluted sample or solvent. The absorbance values were measured using the UV-VIS spectrophotometer at $593 \mathrm{~nm}$ and expressed as $\mu \mathrm{mol} \mathrm{TE} / \mathrm{g}$ compound.

\subsubsection{In Vitro Photoprotection Assay}

Evaluation of Filtering Parameters of Benzothiazole Derivatives in Solution

The evaluation of the sun protection parameters has been carried out using a UV-Vis spectrophotometer. The absorbance of the solutions of the test compounds dissolved in the different solvents (DMSO, $\mathrm{MeOH}, \mathrm{DMSO}-\mathrm{H}_{2} \mathrm{O}$ 4:6, DMSO- $\mathrm{H}_{2} \mathrm{O}$ 6:4, $\mathrm{HE}$ ) at a concentration of $0.0015( \pm 0.000005) \%$ was recorded in the range $290-400 \mathrm{~nm}$ using a $1 \mathrm{~cm}$ quartz cell at $1 \mathrm{~nm}$ intervals. It was decided to evaluate the profile of the compounds in the Peg-7 Glyceryl Cocoate (HE) oil, which is the emollient of choice to solubilize the compounds in a formulation suitable for in vivo analysis. Wavelength absorbance is in relationship with transmittance $(T(\lambda))$ from Equation (2)

$$
A(\lambda)=\log [T(\lambda)]
$$

where $T(\lambda)$ is the fraction of incident irradiance that is transmitted through a sample.

Evaluation of Filtering Parameters of Formulation

The synthesized derivatives were incorporated at increasing concentrations $(1 \%, 2 \%$ and $3 \%$ ) in a topical $\mathrm{W} / \mathrm{O}$ cosmetic standard formulation, to evaluate the filtering parameters, having the following ingredients composition.

INCI (International Nomenclature Cosmetic Ingredients): aqua, glycerin, Euxyl PE 9010, xanthan gum, ceteareth-12, ceteareth-20, sterearic acid, butylhydroxytoluene, myritol, PEG-7 glyceryl cocoate and 10\% sodium solution.

Briefly, the protocol is to finger spread $32.5 \mathrm{mg}$ of each formulation onto $25 \mathrm{~cm} 2$ PMMA plates. Each formulation was tested in triplicate by recording five measurements for each dish, after incubation in the dark for 15-30 min at room temperature. UV transmittance data were recorded in the range $290-400 \mathrm{~nm}$ using a UV-VIS spectrophotometer.

Blank plate, SPF, UVA-PF and Critical Wavelength were achieved through SPF Calculator Software (version 2.1), Shimadzu, Milan, Italy) as previously reported [28].

Photostability Study

The method adopted to determine the photostability has been previously reported [28]. Each plate was prepared as mentioned above and subjected to a solar irradiation quantified as the minimum UVA dose equivalent to an effective erythema radiant exposure. Transmittance of the sunscreen layer was recorded in the range of $290-400 \mathrm{~nm}$ before and after exposure to sunlight.

Equations (3) and (4) made it possible to derive the residual percentage of SPF in vitro (\% SPFeff.) and UVA-PF (\% UVA-PFeff.), respectively, which, if greater than or equal to 80, can categorize a filter as photostable.

$$
\begin{gathered}
\% \mathrm{SPF}_{\text {eff. }}=\text { in vitro } \mathrm{SPF}_{\mathrm{after}} / \text { in vitro } \mathrm{SPF}_{\text {before }} \times 100 \\
\% \mathrm{UVA}-\mathrm{PF}_{\text {eff. }}=\mathrm{UVA}-\mathrm{PF}_{\mathrm{after}} / \mathrm{UVA}-\mathrm{PF}_{\text {before }} \times 100 .
\end{gathered}
$$

\subsubsection{Antifungal Activity}

Microorganisms

The dermatophytes used in this study were Epidermophyton floccosum var. floccosum (Netherlands) CBS 358.93 strain, Trichophyton tonsurans (Netherlands) CBS 483.76 strain, Trichophyton mentagrophytes (Netherlands) CBS 160.66 strain, Microsporum canis (Iran) CBS 131,110 strain, and Microsporum gypseum (Iran) CBS 130,948 strain. All dermatophytes were 
maintained at $4^{\circ} \mathrm{C}$ as agar slants on SDA. Candida albicans (ATCC 10231) was maintained at $4{ }^{\circ} \mathrm{C}$ on SDA plate.

Antidermatophyte Activity

The in vitro antifungal activity against the five selected dermatophytes was evaluated, as previously described [28], using the plaque growth inhibition method. All compounds were evaluated at the final concentration of $100 \mathrm{~g} / \mathrm{mL}$. The percentages of growth inhibition according to Equation (5) were calculated as the average of three different experiments.

$$
\mathrm{I}=[(\mathrm{C}-\mathrm{T}) / \mathrm{C}] \times 100 \%,
$$

where I is the percentage value of growth inhibition, $C$ is the measure of the diameter of the control circular mycelial inoculum $(\mathrm{mm})$ and $\mathrm{T}$ is the extended diameter of the treated mycelial inoculum (mm).

\section{Anti-Candida albicans Activity}

The suspension of Candida albicans consists of the dispersion of an aliquot in $5 \mathrm{~mL}$ of sterilized water. The compounds and fluconazole, used as a positive control, were solubilized in DMSO $(12.80 \mathrm{mg} / \mathrm{mL})$ as stock solutions. Minimum inhibitory concentration (MIC) was performed by the broth microdilution method according to the approved standard M27-A3, 2008 [NCCLS] of the Clinical and Laboratory Standards Institute/National Committee for Clinical Laboratory Standards (CLSI/NCCLS), as described previously [28].

\subsubsection{Anti-Proliferative Activity}

Cells Lines

Human cervical carcinoma (HeLa) and human CD4+T-lymphoblast (CEM) cells were obtained from ATCC (Middlesex, UK). Human pancreatic carcinoma (Mia-Paca 2) cells were kindly provided by Prof. Anna Karlsson (Karolinska Institute, Stockholm, Sweden). All cell lines were grown in Dulbecco's modified Eagle's medium (DMEM; Gibco, Carlsbad, CA, USA), supplemented with 10\% fetal bovine serum (FBS, Gibso), 0.01M Hepes (Gibco) and $1 \mathrm{mM}$ sodium pyruvate (Gibco) in a humidified $5 \% \mathrm{CO}_{2}$ incubator at $37^{\circ} \mathrm{C}$.

\section{Cell Proliferation}

The cell suspensions of CEM, HeLa and Mia-Paca2 were treated with increasing concentrations of the selected compounds, following the protocol previously reported [28].

$\mathrm{IC}_{50}$ Determination

A stock solution of the compounds (20 mM in DMSO) was prepared and stored at $-18{ }^{\circ} \mathrm{C}$. Then, the compounds were diluted in the cell culture medium and tested starting with the $100 \mu \mathrm{M}$ concentration as the upper limit. The application of equation (6) allowed to obtain the values of $\mathrm{IC}_{50}$.

$$
\mathrm{C} 1-[50-\mathrm{N} 1 \% / \mathrm{N} 2 \%-\mathrm{N} 1 \%]-(\mathrm{C} 1-\mathrm{C} 2),
$$

where $\mathrm{C} 1$ is the concentration of the compound which inhibits cell proliferation by more than $50 \%$; C2 is the concentration of the compound which inhibits cell proliferation below $50 \%$; N1\% represents the number of cells (expressed as a percentage of control without compound) obtained in the presence of $\mathrm{C} 1$ and $\mathrm{N} 2 \%$ represents the number of cells (as a percentage of control without compound) obtained in the presence of $\mathrm{C} 2$. 


\section{Results}

\subsection{Chemistry}

As previously described [28], the initial step for the synthesis of 2,6-disubstituted benzothiazole was the preparation of two intermediates according to a modified procedure [33] 4-amino-3-mercaptobenzoic acid hydrochloride (3) and bis(2-amino-4-benzenesulfonamide) disulfide (6).

2-aminobenzothiazole-5-carboxylic acid hydrochloride (2) was obtained by treating 4-aminobenzoic acid with potassium thiocyanate in the presence of bromine in an acid medium at $-5{ }^{\circ} \mathrm{C}$. Compound 3 was obtained by alkaline hydrolysis of $\mathbf{2}$ (Scheme 1 ).<smiles>Nc1ccc(C(=O)O)cc1</smiles>

1 (a)

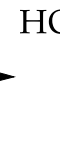<smiles>CCCCCC=C(C)C</smiles>

2<smiles>Nc1ccc(C(=O)O)cc1S</smiles>

3

Scheme 1. Synthesis of 4-amino-3-mercaptobenzoic acid hydrochloride. Reagents and conditions: (a) $\mathrm{AcOH}, \mathrm{KSCN}, \mathrm{Br}_{2},-5{ }^{\circ} \mathrm{C}, \mathrm{HCl}$; (b) $\mathrm{KOH}$, Reflux, $35 \% \mathrm{HCl}$.

The synthesis of 2-aminobenzothiazole-6-sulfonamide (5) was carried out in acetic acid, which, in our experience, is the solvent that allows the best reaction and yield conditions [28]. Bis (2-amino-4-benzenesulfonamide) disulfide (6) was obtained following the treatment of 2-aminobenzothiazole-6-sulfonamide (5) with aqueous potassium hydroxide (Scheme 2), thus allowing the opening of the thiazole ring without hydrolysis of the sulfonamide group.<smiles>Nc1ccc(S(N)(=O)=O)cc1</smiles>
4 (a)<smiles>Nc1nc2ccc(S(N)(=O)=O)cc2s1</smiles>

(b)

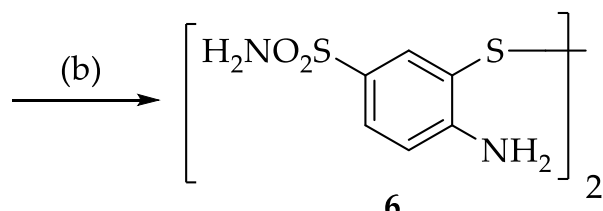

Scheme 2. Synthesis of bis(2-amino-4-benzenesulfonamide)disulfide. Reagents and conditions: (a) $\mathrm{AcOH}, \mathrm{KSCN}, \mathrm{Br}_{2}$ in $\mathrm{AcOH},-5{ }^{\circ} \mathrm{C}, 30 \% \mathrm{NH}_{3}$; (b) $\mathrm{KOH}$, Reflux, 35\% $\mathrm{HCl}$.

Condensation of 3, or $\mathbf{6}$ or 2-aminothiophenol (7) with pyrrole-2-carboxaldehyde (8), furfural (9) or 2-thiophenecarboxaldehyde (10) yielded to the corresponding benzothiazole compounds (8a-c, 9a-c, 10a-c), showed in Scheme 3. All reactions were conducted in ethanol in the presence of sodium hydrosulfite to assess its efficiency as a catalyst.

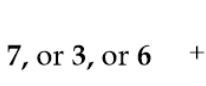<smiles></smiles>

$8,9,10$<smiles></smiles>

$8 a-c, 9 a-c, 10 a-c$

\begin{tabular}{lll} 
& $\mathrm{R}$ & $\mathrm{X}$ \\
\hline $\mathbf{8 a}$ & $\mathrm{H}$ & $\mathrm{NH}$ \\
$\mathbf{8 b}$ & $\mathrm{COOH}$ & $\mathrm{NH}$ \\
$\mathbf{8 c}$ & $\mathrm{SO}_{2} \mathrm{NH}_{2}$ & $\mathrm{NH}$ \\
$\mathbf{9 a}$ & $\mathrm{H}$ & $\mathrm{O}$ \\
$\mathbf{9 b}$ & $\mathrm{COOH}$ & $\mathrm{O}$ \\
$\mathbf{9 c}$ & $\mathrm{SO}_{2} \mathrm{NH}_{2}$ & $\mathrm{O}$ \\
$\mathbf{1 0 a}$ & $\mathrm{H}$ & $\mathrm{S}$ \\
$\mathbf{1 0 b}$ & $\mathrm{COOH}_{2}$ & $\mathrm{~S}$ \\
$\mathbf{1 0 c}$ & $\mathrm{SO}_{2} \mathrm{NH}_{2}$ & $\mathrm{~S}$
\end{tabular}

Scheme 3. Synthesis of compounds 8a-c, 9a-c, 12a-c. Reagents and conditions: (i) EtOH, $\mathrm{Na}_{2} \mathrm{~S}_{2} \mathrm{O}_{4}$ in $\mathrm{H}_{2} \mathrm{O}$, Reflux. 


\subsection{Evaluation of Filtering Parameters}

Because sun protection is related to UV absorption, the spectral behavior of the synthesized compounds was first analyzed to evaluate the lambda max, absorbance and molar extinction coefficient parameters, derived from their spectrum profile in the UVA-UVB range, and compare them with those of the PBSA. The three parameters were determined, respectively, in DMSO and in methanol in order to perform a comparison (Table S1). It was noted for most of the compounds, both in terms of absorbance and lambda max (and consequently, also $\varepsilon$ ), a decrease in the parameters passing from DMSO to methanol. This behavior can be explained by the principle of solvato-chromism which correlates the emission and absorption spectra of a compound with the polarity of the solvent in which it is dissolved. As the polarity of the solvent decreases, there is a shift in the absorption spectrum towards longer wavelengths. In contrast, as the polarity of the solvent increases (as for methanol, in the case of the benzothiazoles analyzed) there is a shift in the absorption spectrum towards shorter wavelengths [36,37].

On the basis of the results obtained (Table S1) and in view of a formulation study, the most promising compounds $(\mathbf{8 a}, \mathbf{9 a}, \mathbf{1 0 a})$ were selected for each class (intended as a type of substituent in position 6 of benzothiazole) to be analyzed in different solvent systems. Since DMSO is a solvent with characteristics very close to those of an oil, the analysis was also carried out in solutions that mimic the possible conditions of a formulation. For this reason, the 4:6 and 6:4 proportions of $\mathrm{DMSO}-\mathrm{H}_{2} \mathrm{O}$ were chosen to evaluate the choice of an oil-in-water or water-in-oil emulsion. It was noted that (Table S2) the solvent system that performed with values most similar to those obtained from the compounds solubilized in $\mathrm{HE}$ was the DMSO- $\mathrm{H}_{2} \mathrm{O}$ 6:4 mixture.

Based on these results obtained, it was decided to proceed by inserting the compounds 8a, 9a, 10a (solubilized in HE) inside a 40:60 W/O emulsion at different concentrations (1\%, $2 \%$ and $3 \%$ ). For the determination of the SPF in vitro of the samples in formulation it was decided to use an internal method, developed by us previously and based on the adaptation of the ISO 24443: 2012 [38]. The transmittance spectrum, processed with a specific software (SPF Calculator), made it possible to obtain the SPF, UVAPF, critical lambda and UVA/UVB ratio values of the formulations containing the selected active ingredients (Table 1).

Table 1. Filtering activity of benzothiazole derivatives in $\mathrm{W} / \mathrm{O}$ formulations.

\begin{tabular}{|c|c|c|c|c|c|}
\hline & Percentage (\%) & SPF & UVAPF & UVA/UVB & $\lambda c(n m)$ \\
\hline \multirow{3}{*}{ PBSA } & 1 & 3.22 & 0.94 & 0.33 & 319 \\
\hline & 2 & 4.63 & 0.94 & 0.22 & 321 \\
\hline & 3 & 5.09 & 1.02 & 0.25 & 324 \\
\hline \multirow{3}{*}{ Lead 10} & 1 & 2.44 & 1.16 & 0.70 & 341 \\
\hline & 2 & 2.72 & 1.32 & 0.73 & 357 \\
\hline & 3 & 3.06 & 1.54 & 0.75 & 364 \\
\hline \multirow{3}{*}{$8 a$} & 1 & 4.19 & 2.17 & 1.17 & 354 \\
\hline & 2 & 7.16 & 2.46 & 0.92 & 353 \\
\hline & 3 & 13.05 & 2.88 & 0.66 & 354 \\
\hline \multirow{3}{*}{$9 a$} & 1 & 6.42 & 1.26 & 0.34 & 337 \\
\hline & 2 & 14.18 & 1.60 & 0.18 & 341 \\
\hline & 3 & 20.23 & 1.50 & 0.13 & 343 \\
\hline \multirow{3}{*}{$10 a$} & 1 & 4.86 & 1.60 & 0.69 & 347 \\
\hline & 2 & 5.14 & 1.60 & 0.62 & 347 \\
\hline & 3 & 10.73 & 2.02 & 0.45 & 349 \\
\hline
\end{tabular}


Compared to PBSA and lead compound 10, all synthesized benzothiazoles provided greater protection against UVB radiation. Different concentrations of PBSA (range 1$3 \%(\mathrm{w} / \mathrm{w}))$ produced SPF values between 3.22 and 5.09, while the lead compound $\mathbf{1 0}$ (benzimidazole bearing pyrrole in position 2 and unsubstituted in position 6) showed SPF values between 2.44 and 3.06 .

Based on the concept of bioisosterism, the substitution of the basic skeleton with benzothiazole has increased the activity sought; therefore, compounds $8 \mathbf{8}, \mathbf{9 a}$ and $\mathbf{1 0 a}$ showed a good photoprotection against UVB. In addition, among benzothiazole derivatives, compound 9a bearing furan at position 2 was the best UVB-photoprotective candidate with in vitro SPF values ranging from 6.42 to 20.23 ; then followed by 8a bearing pyrrole at position 2 showing SPF values ranging from 4.19 to 13.05; and at the end, compound 10a bearing thiophene at position 2 with in vitro SPF values ranged from 4.83 to 10.73 . Because these compounds are not used in combination with others organic or inorganic filters, the results obtained are considered very good as compared to commercial sunscreens; this is confirmed by compound 9a which gave at 3\% an SPF value of 20.23 .

From the results obtained, it was possible to deduce that the order of protection against UVB of the newly synthesized benzothiazole derivatives is the following: furan-> pyrrole-> thiophene-derivatives, as previously seen for the benzimidazole analogue derivatives [31].

UVA protection was given by UVA-PF, which should be at least $1 / 3$ of SPF to be considered efficient (Cosmetic Europe recommendation), this consent to the finished product to show the pictogram "UVA circled" on the label. All synthesized compounds had UVA-PF values higher than the PBSA filter. However, among these values, only compound 8a had a good UVA protection profile. Furthermore, the FDA considers that a product to be broad spectrum should have a $\lambda c \geq 370 \mathrm{~nm}$ [39]: none of the new compounds analyzed can therefore be considered broad spectrum.

Photostability is a crucial feature to delineate the efficacy and safety profile of a solar formulation. According to the criteria developed by Garoli et al. [40], photodegradation was measured by recording the pre- and post-irradiation transmittance of PMMA plates with finger-coated formulations, applying the dose of UVA necessary to cause erythema.

The residual efficacy after exposure (\%) indicates the loss of sun protection after sun exposure. Equations (3) and (4) made it possible to derive the residual percentage of SPF in vitro (\% SPFeff.) and UVA-PF (\% UVA-PFeff.), respectively, which, if greater than or equal to 80, make a filter to be categorized as photostable, according to regulation [41]. It can be deduced from the data obtained that compounds 8a and 10a were photostable (Figure 2). In particular, the compound 10a, which brings a thiophene in position 2, proved to be photostable in the whole UV spectrum. However, compound 8a, with a pyrrole in position 2, was found to be more photostable in the UVA range rather than the UVB range. Compound 9a containing furan in position 2 was photo-unstable with SPF and PF-UVA below $80 \%$, and this could be attributable to photo-instability of its conjugated species [42]. The order of photostability that emerged for the benzothiazole derivatives is: thiophene derivatives $>$ pyrrole derivatives $>$ furan derivatives. 


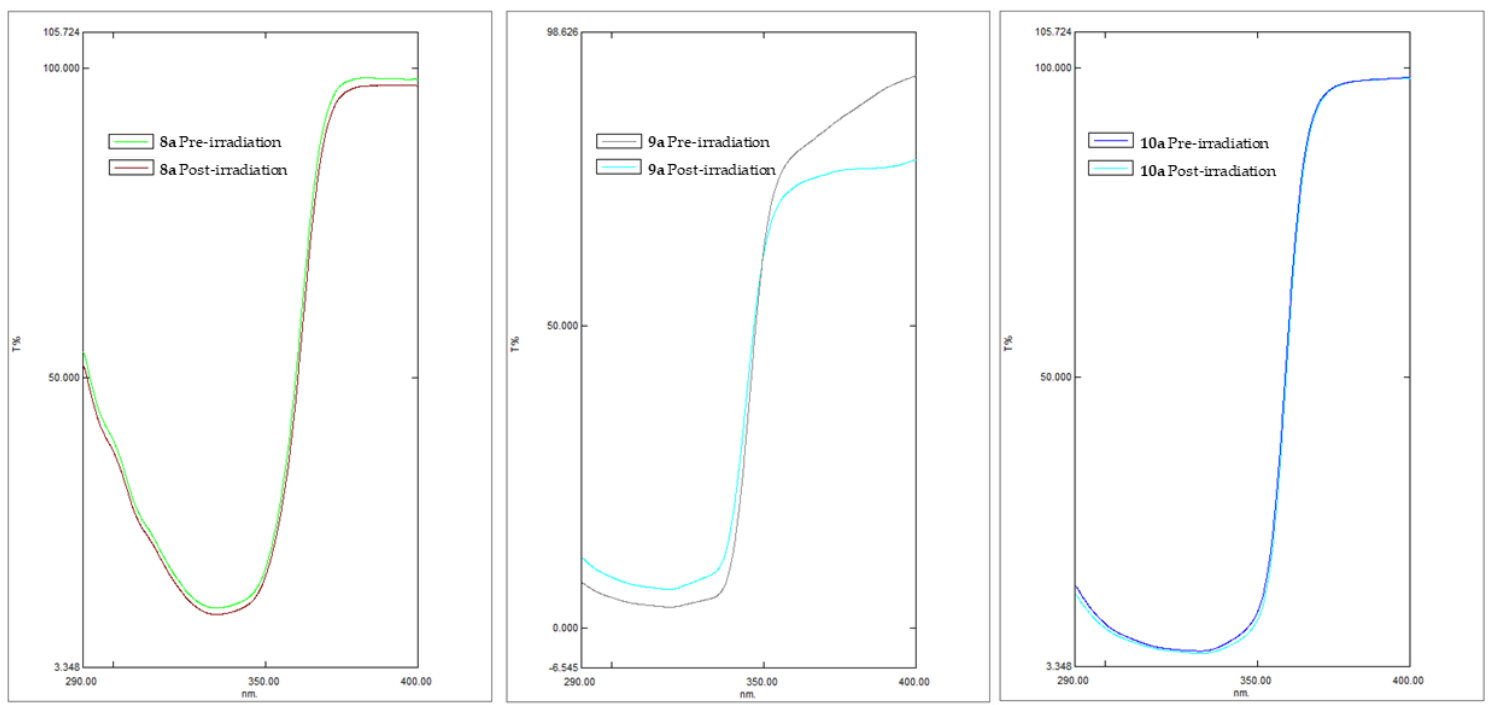

Figure 2. Pre- and post-irradiation transmittance profiles of formulations studied containing benzothiazole derivatives $8 \mathbf{a}, \mathbf{9 a}$, and $10 \mathbf{a}$.

\subsection{In Vitro Antioxidant Profile}

The antioxidant activity of a molecule is very important and, if present, it can be synergistic with the SPF described above in reducing the damage that is ROS-induced by UV rays. For this reason, the synthesized compounds were assayed in vitro to assess their antioxidant profiles by means of the DPPH and FRAP assays (Table 2). Regarding the ability to scavenge the stable radical 2,2-diphenyl-1-picrylhydrazyl (DPPH), it was decided to investigate first the compounds synthesized at the same concentration $(1 \mathrm{mg} / \mathrm{mL})$ and evaluate the percentage of inhibition of the radical DPPH.

Table 2. DPPH and FRAP in vitro activity of the synthesized compounds. Each value is the mean of at least three different experiments (mean \pm SEM). ${ }^{*}$ Limit of Quantification (LOQ).

\begin{tabular}{|c|c|c|c|}
\hline Compound & DPPH (\% Inhibition) & DPPH IC ${ }_{50}(\mathrm{mg} / \mathrm{mL})$ & FRAP $(\mu \mathrm{molTE} / \mathrm{g})$ \\
\hline PBSA & $<\mathrm{LOQ}^{*}$ & - & $<\mathrm{LOQ}^{*}$ \\
\hline Caffeic acid & $80.15 \pm 1.24$ & - & $10125.48 \pm 32.87$ \\
\hline Lead 10 & $70.00 \pm 3.25$ & $0.064 \pm 0.003$ & $1085.57 \pm 0.88$ \\
\hline $8 a$ & $29.17 \pm 1.05$ & - & $329.85 \pm 0.94$ \\
\hline $8 b$ & $5.71 \pm 0.37$ & & $373.15 \pm 1.27$ \\
\hline $8 c$ & $45.24 \pm 2.78$ & - & $119.12 \pm 1.49$ \\
\hline $9 a$ & $24.69 \pm 0.14$ & - & $72.34 \pm 3.42$ \\
\hline $9 b$ & $9.49 \pm 0.04$ & - & $66.07 \pm 8.23$ \\
\hline $9 \mathrm{c}$ & $64.92 \pm 0.91$ & - & $150.34 \pm 11.01$ \\
\hline $10 a$ & $85.00 \pm 0.88$ & $1.68 \pm 0.012$ & $143.13 \pm 3.84$ \\
\hline $10 b$ & $46.04 \pm 0.07$ & - & $133.91 \pm 8.13$ \\
\hline $10 \mathrm{c}$ & $21.82 \pm 0.06$ & - & $60.90 \pm 1.87$ \\
\hline
\end{tabular}

From the results reported in Table 2, it can be observed that PBSA is devoid of any antioxidant activity, while the reference compound $\mathbf{1 0}$ has a good profile towards the DPPH radical. In general, it can be stated that the substitution of the benzimidazole nucleus (compound 10) with benzothiazole has led to a reduction of the antioxidant profile, with the exception of compound 10a. The insertion in position 2 of benzothiazole with five- 
membered rings led to molecules with a low significant in vitro antioxidant activity profile (Table 2).

Based on this first screening, only compound 10a (85\% inhibition) was further investigated to determine the $\mathrm{IC}_{50}$ value, which was found to be equal to $1.68 \mathrm{mg} / \mathrm{mL}$, therefore decidedly lower than the $\mathrm{IC}_{50}$ value of compound 10. Regarding the ability to reduce ferrous ions to ferrous (FRAP test), none of the compounds showed an activity of interest in terms of antioxidant capacity.

\subsection{Antifungal Activity}

All synthesized benzothiazole derivatives were evaluated to evaluate their in vitro antifungal activity against the five pathogenic dermatophytes that cause the most common dermatomycoses: Microsporum gypseum, Microsporum canis, Trichophyton mentagrophytes, Trichophyton tonsurans and Epidermophyton floccosum. All compounds were tested at a concentration of $100 \mu \mathrm{g} / \mathrm{mL}$ in DMSO, to evaluate the ability to inhibit the growth of dermatophyte cultures in Sabouraud Dextrose Agar (SDA). Briefly, room temperature incubation was performed and dermatophyte inhibition assessed by measuring the colony diameter at each disc for 7 days. The results are shown in Table 3 and were determined as the average of three different experiments.

Table 3. Antifungal capacity of the benzothiazole derivatives tested at $100 \mu \mathrm{g} / \mathrm{mL}$, expressed as the average of the percentage of growth inhibition of at least three measurements (mean $\pm \mathrm{SEM}$ ).

\begin{tabular}{cccccc}
\hline & & \multicolumn{3}{c}{ \% Inhibition Growth } \\
\hline Compound & M. gypseum & M. canis & T. mentagrophytes & T. tonsurans & E. floccosum \\
\hline PBSA & $9.44 \pm 0.35$ & + & + & + & $7.28 \pm 0.56$ \\
\hline Lead 10 & $99.07 \pm 1.33$ & $96.85 \pm 3.56$ & $96.26 \pm 2.42$ & $96.97 \pm 0.62$ & $101.75 \pm 4.92$ \\
\hline $\mathbf{8 a}$ & $50.00 \pm 1.34$ & $25.00 \pm 1.61$ & $10.00 \pm 0.51$ & $7.46 \pm 0.05$ & $26.00 \pm 0.66$ \\
\hline $\mathbf{8 b}$ & + & + & + & $5.45 \pm 0.12$ & + \\
\hline $\mathbf{8 c}$ & $23.08 \pm 0.48$ & $23.31 \pm 0.86$ & $2.36 \pm 0.17$ & $2.25 \pm 0.03$ & $24.69 \pm 0.71$ \\
\hline 9a & $74.78 \pm 0.59$ & $63.95 \pm 0.72$ & $53.98 \pm 0.99$ & $57.89 \pm 0.76$ & $68.85 \pm 0.54$ \\
\hline 9b & $18.07 \pm 0.97$ & $14.47 \pm 0.83$ & + & $29.76 \pm 1.23$ & $5.48 \pm 0.12$ \\
\hline 9c & $17.82 \pm 0.06$ & $19.48 \pm 1.20$ & $10.97 \pm 0.08$ & + & $36.36 \pm 1.25$ \\
\hline 10a & $70.43 \pm 0.77$ & $65.99 \pm 0.82$ & $61.95 \pm 0.44$ & $64.47 \pm 0.92$ & $54.10 \pm 0.75$ \\
\hline 10b & $18.48 \pm 1.23$ & $27.59 \pm 1.47$ & $14.15 \pm 1.01$ & $65.45 \pm 1.58$ & $28.26 \pm 1.04$ \\
\hline 10c & $12.36 \pm 0.05$ & $14.29 \pm 0.70$ & $10.92 \pm 0.09$ & $6.35 \pm 0.02$ & $10.71 \pm 0.31$ \\
\hline Fluconazole & $18.20 \pm 0.90$ & $30.1 \pm 0.40$ & $3.75 \pm 0.24$ & $18.74 \pm 0.62$ & $0.12 \pm 0.004$ \\
\hline
\end{tabular}

+ indicates that compound stimulates fungal growth.

Starting from the PBSA, which showed no activity on the selected microorganisms, and replacing phenyl with pyrrole, a compound (10) was obtained with an excellent activity profile on all five dermatophytes, indicating the importance of the five members ring for the investigated activity.

As for the previously reported benzimidazole derivatives [31], position 6 unsubstituted benzothiazole compounds (compounds 8a, 9a and 10a), in general, showed the best values of inhibition. In particular, compounds 9a and 10a showed a good inhibition of the growth of all five dermatophytes (with percentages of inhibition between $50 \%$ and $75 \%$ ). Furthermore, benzothiazoles bearing $-\mathrm{COOH}$ or $-\mathrm{SO}_{2} \mathrm{NH}_{2}$ did not show significant activity on dermatophytes, with the exception of compound $10 \mathrm{~b}$ which showed $65.45 \%$ inhibition on T. tonsurans, suggesting that the electron-attracting substituent reduces antifungal activity.

The antifungal profile of this class of benzothiazole derivatives has highlighted that it is not the substitution of pyrrole with thiophene or furan that most influences the variability of activity but rather that, in terms of structure-activity relationship, it is the presence of hydrogen in the position 6 of the benzothiazole ring to be more advantageous than the 
electron-withdrawing group. Furthermore, almost all the compounds tested were more active than fluconazole, the reference agent for antifungal tests.

Candida is a strain of fungi known to transmit infections to different parts of the human body, including the skin [43], which is why the synthesized compounds have also been tested against Candida Albicans (ATCC 10231). For each of them the minimum inhibitory concentration (MIC) was determined by the broth microdilution method using RPMI $1640+$ MOPS as culture medium. Following incubation at $37{ }^{\circ} \mathrm{C}$ for 24 and 48 $\mathrm{h}$ of the compounds $(0.25 \mu \mathrm{g} / \mathrm{mL}$ to $12.48 \mu \mathrm{g} / \mathrm{mL})$ growth was observed in the 96-well plate by visually observing turbidity and determining inhibition from absence of growth. Fluconazole was used as a positive control drug. IC was established as the minimum sample concentration that does not develop turbidity, and the results obtained are shown in Table 4 (only compounds active against Candida albicans were shown). Compounds 9a and 10a showed activity against Candida albicans after $24 \mathrm{~h}$. Similarly to the results observed on dermatophytes, therefore, the unsubstituted compounds in position 6 of benzimidazole gave activity on yeasts, except for compound $\mathbf{8 a}$.

Table 4. Anti-Candida albicans activity of synthesized compounds. The values refer to 24 and $48 \mathrm{~h}$ of incubation. MICs represent the mean value of a triplicate.

\begin{tabular}{cccc}
\hline & & (MIC $\mu \mathrm{g} / \mathrm{mL})$ \\
\hline Compound & $24 \mathrm{~h}$ & $48 \mathrm{~h}$ \\
\hline Fluconazole & 0.5 & - \\
\hline Lead 10 & - & - \\
\hline 9a & 32 & - \\
\hline 10a & 64 & - \\
\hline
\end{tabular}

\subsection{Antiproliferative Activity}

Finally, the compounds of this series of benzothiazole derivatives were tested to evaluate their antiproliferative activity in vitro against human T-cell leukemia cell line (CEM), human cervical carcinoma cells (HeLa), human pancreas cancer cells (Mia Paca-2) and human melanoma cells (SK-Mel 5). Non-cancerous HEK293T cells (Normal Kidney Epithelial Cells) were chosen as a control for cytotoxicity and/or selectivity. The results obtained have been summarized in Table 5 (data shown only for the active compounds) and are expressed as $\mathrm{IC}_{50}$ values in $\mu \mathrm{M}$. The selectivity index (SI) was also reported, determined by comparing the values of $\mathrm{IC}_{50}(\mu \mathrm{M})$ obtained on healthy cells (HEK 293) with that obtained on tumor cells (CEM, HeLa, Mia-Paca-2 and SK- Mel 5) (Table 5). According to the results obtained, unsubstituted at position 6 derivatives of benzothiazole proved to have the best activity profile on different tumor cell lines, even if compound $\mathbf{8 a}$, bearing pyrrole in position 2, showed cytotoxic activity against the control cell line (HEK293T). Compound 10c also emerged from antiproliferative assays, showing a good inhibition against Mia Paca-2 with an $\mathrm{IC}_{50}$ value of $13 \mu \mathrm{M}$ and a selectivity index higher than 7 . 
Table 5. Antiproliferative activity of benzothiazole compounds against CEM, HeLa, Mia Paca-2 and SK-Mel 5. All the values are the mean of at least three different experiments.

\begin{tabular}{|c|c|c|c|c|c|c|c|c|c|}
\hline \multirow[b]{2}{*}{ Compound } & \multicolumn{5}{|c|}{$\mathrm{IC}_{50}(\mu \mathrm{M})$} & \multicolumn{4}{|c|}{ SI } \\
\hline & CEM & HeLa & Mia-Paca2 & SK-Mel5 & Hek293 & CEM & HeLa & Mia-Paca2 & SK-Mel5 \\
\hline Reference 10 & $14 \pm 1$ & $37 \pm 0$ & $15 \pm 9$ & $9.7 \pm 1.7$ & $31 \pm 3$ & 2.21 & - & 2.07 & 3.20 \\
\hline $8 a$ & $>100$ & $65 \pm 2$ & $87 \pm 18$ & $41 \pm 4$ & $68 \pm 14$ & - & 1.04 & - & 1.66 \\
\hline $9 a$ & $41 \pm 5$ & $>100$ & $>100$ & $98 \pm 2$ & $>100$ & 2.44 & - & - & 1.02 \\
\hline $10 a$ & $45 \pm 3$ & $>100$ & $>100$ & $50 \pm 5$ & $>100$ & 2.22 & - & - & 2.00 \\
\hline $10 \mathrm{c}$ & $>100$ & $>100$ & $13 \pm 3$ & $>100$ & $>100$ & - & - & 7.69 & - \\
\hline
\end{tabular}

\section{Conclusions}

The aim of the present study was to improve the activity profile of previously discovered benzimidazole-structured compounds by isosteric substitution of the base nucleus with a variously substituted benzothiazole in position 2 . The synthesis of this new class of benzothiazole derivatives was therefore aimed at identifying molecules with a multifunctional biological profile, with particular attention to pathologies affecting the skin. For this reason, one of the fundamental aspects of this work concerned the ability of the molecules to provide photoprotection and therefore to safeguard against the harmful effects induced by both direct (UVB) and indirect (UVA) exposure to UV rays.

To arouse greater interest in this new synthesized series were compounds $9 \mathbf{a}$ and $\mathbf{1 0 a}$, for which a multifunctional profile was outlined supported by an excellent filtering capacity (especially for 9a) whose data highlighted a mainly UVB and higher filtering capacities than those of the PBSA. Compound 9a, however, was found to be photo-unstable.

At the same time, the two compounds showed, compared to the other synthetic products of the series, the best results in terms of the growth inhibition of dermatophytes and Candida albicans (within $24 \mathrm{~h}$ ).

In terms of both the inhibition of the DPPH radical and the reduction capacity of the ferric ion, compound 10a prevailed, since 9a did not have a good antioxidant profile. As regards the data obtained from the anticancer tests, the derivative 9 a showed a better profile than 10a, especially on melanoma tumor cells (SK-Mel 5).

The synthesized compounds were also inserted into a large general screening project aimed to discover compounds effective on pancreatic tumor cells. Among the synthesized derivatives, 10c gave excellent results on pancreatic cancer cells (Mia-Paca 2). Finally, $\mathbf{8 b}$ is also worth being mentioned because it showed the best results in the FRAP test.

The results obtained from this study have therefore underlined the real potential of the benzothiazole scaffold being suitably substituted as a basis for the design of multifunctional compounds. In particular, compounds $9 \mathbf{a}, \mathbf{1 0 a}, \mathbf{1 0 c}$ and $\mathbf{8 b}$ represent interesting hints in the development of more effective compounds through further structural modifications. Future studies will involve the in vitro and in vivo evaluation of selected formulations to investigate aspects such as the possible development of side effects such as allergies and dermatitis that could limit their application in the dermatologic and cosmeceutical field.

Supplementary Materials: The following are available online at https://www.mdpi.com/article/10 .3390 /antiox11020407/s1, Table S1: Parameter values obtained from the UV spectra of the synthesized compounds solubilized in DMSO and $\mathrm{MeOH}$, Table S2: Parameter values obtained from the UV spectra of the selected compounds solubilized in different combination of solvents, Table S3: List of synthesized compounds, Figure S1: ${ }^{1} \mathrm{H}-\mathrm{NMR}$ spectrum of compound 8a, Figure S2: ${ }^{13} \mathrm{C}-\mathrm{NMR}$ spectrum of compound 8a, Figure S3: ${ }^{1} \mathrm{H}-\mathrm{NMR}$ spectrum of compound $\mathbf{8 b}$, Figure S4: ${ }^{13} \mathrm{C}-\mathrm{NMR}$ spectrum of compound $\mathbf{8 b}$, Figure S5: ${ }^{1} \mathrm{H}-\mathrm{NMR}$ spectrum of compound 8c, Figure S6: ${ }^{13} \mathrm{C}-\mathrm{NMR}$ spectrum of compound 8c, Figure S7: ${ }^{1} \mathrm{H}-\mathrm{NMR}$ spectrum of compound 9a, Figure S8: ${ }^{13} \mathrm{C}-\mathrm{NMR}$ spectrum of compound 9a, Figure S9: ${ }^{1} \mathrm{H}-\mathrm{NMR}$ spectrum of compound 9b, Figure S10: ${ }^{13} \mathrm{C}-\mathrm{NMR}$ spectrum of compound $\mathbf{9 b}$, Figure S11: ${ }^{1} \mathrm{H}-\mathrm{NMR}$ spectrum of compound 9c, Figure S12: ${ }^{13} \mathrm{C}-\mathrm{NMR}$ 
spectrum of compound 9c, Figure S13: ${ }^{1} \mathrm{H}-\mathrm{NMR}$ spectrum of compound 10a, Figure S14: ${ }^{13} \mathrm{C}-\mathrm{NMR}$ spectrum of compound 10a. Figure S15: ${ }^{1} \mathrm{H}-\mathrm{NMR}$ spectrum of compound 10b, Figure S16: ${ }^{13} \mathrm{C}-\mathrm{NMR}$ spectrum of compound 10b. Figure S17: ${ }^{1} \mathrm{H}-\mathrm{NMR}$ spectrum of compound 10c, Figure S18: ${ }^{13} \mathrm{C}-\mathrm{NMR}$ spectrum of compound 10c.

Author Contributions: Conceptualization, A.B., S.V. and S.M.; formal analysis, E.N.D., R.B., E.D., S.S. and S.L.; investigation, E.N.D., R.B., A.B. and S.V.; data curation, A.B., J.B.; writing-original draft preparation, A.B., S.V., E.N.D.; writing-review and editing, A.B., S.V. and S.M.; supervision, A.B., S.M.; project administration, S.M.; funding acquisition, A.B., S.V., S.M. All authors have read and agreed to the published version of the manuscript.

Funding: This research was funded by University of Ferrara (Grant FAR 2020 to AB), Ambrosialab srl (Ferrara, Italy) and by the Italian Ministero dell'Istruzione, Università e della Ricerca (PRIN 2017, Prot. No. 2010E84AA4_002).

Institutional Review Board Statement: Not applicable.

Informed Consent Statement: Not applicable.

Data Availability Statement: Data is contained within the article and Supplementary Materials.

Conflicts of Interest: Authors declare no conflict of interest.

\section{References}

1. Bansal, Y.; Silakari, O. Multifunctional compounds: Smart molecules for multifactorial diseases. Eur. J. Med. Chem. 2014, 76, 31-42. [CrossRef] [PubMed]

2. Maggiora, G. The reductionist paradox: Are the laws of chemistry and physics sufficient for the discovery of new drugs? J. Comput. Aided. Mol. Des. 2011, 25, 699-708. [CrossRef] [PubMed]

3. Keith, C.T.; Borisy, A.A.; Stockwell, B.R. Multicomponent therapeutics for networked systems. Nat. Rev. Drug Discov. 2005, 4, 71-78. [CrossRef] [PubMed]

4. Eisen, S.A.; Miller, D.K.; Woodward, R.S.; Spitznagel, E.; Przybeck, T.R. The effect of prescribed daily dose frequency on patient medication compliance. Arch. Intern. Med. 1990, 150, 1881-1884. [CrossRef]

5. Hohl, C.M.; Dankoff, J.; Colacone, A.; Afilalo, M. Polypharmacy, adverse drug-related events, and potential adverse drug interactions in elderly patients presenting to an emergency department. Ann. Emerg. Med. 2001, 38, 666-671. [CrossRef]

6. Reddy, A.S.; Zhang, S. Polypharmacology: Drug discovery for the future. Expert Rev. Clin. Pharmacol. 2013, 6, 41-47. [CrossRef]

7. Morphy, R.; Kay, C.; Rankovic, Z. From magic bullets to designed multiple ligands. Drug Discov. Today 2004, 9, 641-651. [CrossRef]

8. Medina-Franco, J.L.; Giulianotti, M.A.; Welmaker, G.S.; Houghten, R.A. Shifting from the single to the multitarget paradigm in drug discovery. Drug Discov. Today 2013, 18, 495-501. [CrossRef]

9. Morphy, R.; Rankovic, Z. Designed Multiple Ligands. An Emerging Drug Discovery Paradigm. J. Med. Chem. 2005, 48, 6523-6543. [CrossRef]

10. Cavalli, A.; Bolognesi, M.L.; Minarini, A.; Rosini, M.; Tumiatti, V.; Recanatini, M.; Melchiorre, C. Multi-target-Directed Ligands To Combat Neurodegenerative Diseases. J. Med. Chem. 2008, 51, 347-372. [CrossRef]

11. Youdim, M.B.H.; Buccafusco, J.J. CNS Targets for multi-functional drugs in the treatment of Alzheimer's and Parkinson's diseases. J. Neural Transm. 2005, 112, 519-537. [CrossRef] [PubMed]

12. Thakur, P.; Kumar, A.; Kumar, A. Targeting oxidative stress through antioxidants in diabetes mellitus. J. Drug Target. 2018, 26, 766-776. [CrossRef] [PubMed]

13. Schieber, M.; Chandel, N.S. ROS Function in Redox Signaling and Oxidative Stress. Curr. Biol. 2014, 24, R453-R462. [CrossRef] [PubMed]

14. Chen, Q.; Wang, Q.; Zhu, J.; Xiao, Q.; Zhang, L. Reactive oxygen species: Key regulators in vascular health and diseases. J. Cereb. Blood Flow Metab. 2017, 175, 1279-1292. [CrossRef]

15. Oztanir, M.N.; Ciftci, O.; Cetin, A.; Aladag, M.A. Hesperidin attenuates oxidative and neuronal damage caused by global cerebral ischemia/reperfusion in a C57BL/J6 mouse model. Neurol. Sci. 2014, 35, 1393-1399. [CrossRef]

16. Zheng, X.-J.; Li, C.-S.; Cui, M.-Y.; Song, Z.-W.; Bai, X.-Q.; Liang, C.-W.; Wang, H.-Y.; Zhang, T.-Y. Synthesis, biological evaluation of benzothiazole derivatives bearing a 1,3,4-oxadiazole moiety as potential anti-oxidant and anti-inflammatory agents. Bioorganic Med. Chem. Lett. 2020, 30, 127237. [CrossRef]

17. Okoh, O.A.; Bisby, R.H.; Lawrence, C.L.; Rolph, C.E.; Smith, R.B. Promising near-infrared non-targeted probes: Benzothiazole heptamethine cyanine dyes. J. Sulfur Chem. 2013, 35, 42-56. [CrossRef]

18. Cao, Z.; Qiu, F.; Wang, Q.; Cao, G.; Zhuang, L.; Shen, Q.; Xu, X.; Wang, J.; Chen, Q.; Yang, D. Synthesis of azo benzothiazole polymer and its application of $1 \times 2$ Y-branched and $2 \times 2$ Mach-Zehnder interferometer switch. Optik 2013, 124, 4036-4040. [CrossRef] 
19. Rajeeva, B.; Srinivasulu, N.; Shantakumar, S.M. Synthesis and Antimicrobial Activity ofSome New 2-Substituted Benzothiazole Derivatives. E-J. Chem. 2009, 6, 775-779. [CrossRef]

20. Yadav, A.G.; Patil, V.N.; Asrondkar, A.L.; Naik, A.A.; Ansulkar, P.V.; Bobade, A.S.; Chowdhary, A.S. Antioxidant and antimicrobial activities of pyrazolyl-benzothiazole derivatives using vilsmeir-haack reaction. Ras. J. Chem. 2012, 5, 117-120.

21. Sharma, P.C.; Sinhmar, A.; Sharma, A.; Rajak, H.; Pathak, D.P. Medicinal significance of benzothiazole scaffold: An insight view. J. Enzym. Inhib. Med. Chem. 2012, 28, 240-266. [CrossRef] [PubMed]

22. Sana, T.; Payal, K.; Mohammad, A. Therapeutic advancement of benzothiazole derivatives in the last decennial period. Arch Pharm. Chem. Life Sci. 2019, 352, e1800170.

23. Amaro-Ortiz, A.; Yan, B.; D'Orazio, J.A. Ultraviolet Radiation, Aging and the Skin: Prevention of Damage by Topical cAMP Manipulation. Molecules 2014, 19, 6202-6219. [CrossRef] [PubMed]

24. Saewan, N.; Jimtaisong, A. Natural products as photoprotection. J. Cosmet. Dermatol. 2015, 14, 47-63. [CrossRef]

25. Onnis, V.; Demurtas, M.; Deplano, A.; Balboni, G.; Baldisserotto, A.; Manfredini, S.; Pacifico, S.; Liekens, S.; Balzarini, J. Design, Synthesis and Evaluation of Antiproliferative Activity of New Benzimidazolehydrazones. Molecules 2016, 21, 579. [CrossRef]

26. Demurtas, M.; Baldisserotto, A.; Lampronti, I.; Moi, D.; Balboni, G.; Pacifico, S.; Vertuani, S.; Manfredini, S.; Onnis, V. Indole derivatives as multifunctional drugs: Synthesis and evaluation of antioxidant, photoprotective and antiproliferative activity of indole hydrazones. Bioorganic Chem. 2019, 85, 568-576. [CrossRef]

27. Baldisserotto, A.; Demurtas, M.; Lampronti, I.; Tacchini, M.; Moi, D.; Balboni, G.; Vertuani, S.; Manfredini, S.; Onnis, V. In-vitro evaluation of antioxidant, antiproliferative and photo-protective activities of benzimidazole hydrazone derivatives. Pharmaceuticals 2020, 13, 68. [CrossRef]

28. Djuidje, E.N.; Sciabica, S.; Buzzi, R.; Dissette, V.; Balzarini, J.; Liekens, S.; Serra, E.; Andreotti, E.; Manfredini, S.; Vertuani, S.; et al. Design, synthesis and evaluation of benzothiazole derivatives as multifunctional agents. Bioorganic Chem. 2020, 101, 103960. [CrossRef]

29. Baldisserotto, A.; Demurtas, M.; Lampronti, I.; Tacchini, M.; Moi, D.; Balboni, G.; Pacifico, S.; Vertuani, S.; Manfredini, S.; Onnis, V. Synthesis and evaluation of antioxidant and antiproliferative activity of 2-arylbenzimidazoles. Bioorganic Chem. 2019, $94,103396$. [CrossRef]

30. Brenner, M.; Hearing, V.J. The Protective Role of Melanin Against UV Damage in Human Skin. Photochem. Photobiol. 2008, 84, 539-549. [CrossRef]

31. Djuidje, E.N.; Durini, E.; Sciabica, S.; Serra, E.; Balzarini, J.; Liekens, S.; Manfredini, S.; Vertuani, S.; Baldisserotto, A. Skin Damages-Structure Activity Relationship of Benzimidazole Derivatives Bearing a 5-Membered Ring System. Molecules 2020, 25, 4324. [CrossRef] [PubMed]

32. Idhayadhulla, A.; Kumar, R.S.; Nasser, A.J.A.; Manilal, A. Synthesis of Some New Pyrrole and Pyridine Derivatives and their Antimicrobial, Anticancer Activities. Int. J. Biol. Chem. 2012, 7, 15-26. [CrossRef]

33. Weekes, A.A.; Bagley, M.C.; Westwell, A.D. An efficient synthetic route to biologically relevant 2-phenylbenzothiazoles substituted on the benzothiazole ring. Tetrahedron 2011, 67, 7743-7747. [CrossRef]

34. Wang, M.; Li, J.; Rangarajan, M.; Shao, Y.; LaVoie, E.J.; Huang, T.-C.; Ho, C.-T. Antioxidative Phenolic Compounds from Sage (Salvia officinalis). J. Agric. Food Chem. 1998, 46, 4869-4873. [CrossRef]

35. Benzie, I.F.F.; Strain, J.J. The ferric reducing ability of plasma as a measure of antioxidant power: The FRAP assay. Anal. Biochem. 1996, 239, 70-76. [CrossRef] [PubMed]

36. Mortimer, C.G.; Wells, G.; Crochard, J.P.; Stone, E.L.; Bradshaw, T.D.; Stevens, M.F.G.; Westwell, A.D. Antitumor benzothiazoles 26.(1) 2-(3,4-dimethoxyphenyl)-5-fluorobenzothiazole (GW 610, NSC 721648), a simple fluorinated 2-arylbenzothiazole, shows potent and selective inhibitory activity against lung, colon, and breast cancer cell lines. J. Med. Chem. 2006, 49, 179-185. [CrossRef]

37. Diffey, B.; Robson, J. A New Substrate to Measure Sunscreen Protection Factors Throughout the Ultraviolet Spectrum. J. Soc. Cosmet. Chem. 1989, 40, 127-133.

38. Cvetkovska, A.D.; Manfredini, S.; Ziosi, P.; Molesini, S.; Dissette, V.; Magri, I.; Scapoli, C.; Carrieri, A.; Durini, E.; Vertuani, S. Factors affecting SPF in vitro measurement and correlation with in vivo results. Int. J. Cosmet. Sci. 2016, 39, 310-319. [CrossRef]

39. U.S. Food and Drug Administration. 21 CFR Parts 347 and 352, Sunscreen Drug Products for Over-the-Counter Human Use; Proposed Amendment of Final Monograph, Silver Spring, MD (USA). 2007. Available online: https://www.fda.gov/OHRMS/ DOCKETS/98fr/cd031.pdf (accessed on 25 April 2017).

40. Garoli, D.; Pelizzo, M.G.; Bernardini, B.; Nicolosi, P.; Alaibac, M. Sunscreen tests: Correspondence between in vitro data and values reported by the manufacturers. J. Dermatol. Sci. 2008, 52, 193-204. [CrossRef]

41. Hojerová, J.; Medovcíková, A.; Mikula, M. Photoprotective efficacy and photostability of fifteen sunscreen products having the same label SPF subjected to natural sunlight. Int. J. Pharm. 2011, 408, 27-38. [CrossRef]

42. Varni, A.J.; Fortney, A.; Baker, M.A.; Worch, J.C.; Qiu, Y.; Yaron, D.; Bernhard, S.; Noonan, K.J.T.; Kowalewski, T. Photostable Helical Polyfurans. J. Am. Chem. Soc. 2019, 141, 8858-8867. [CrossRef] [PubMed]

43. Kühbacher, A.; Burger-Kentischer, A.; Rupp, S. Interaction of Candida Species with the Skin. Microorganisms 2017, 5, 32. [CrossRef] [PubMed] 